Wojciech Matuszewski ${ }^{1}$, Elżbieta Bandurska-Stankiewicz ${ }^{1}$, Robert Modzelewski ${ }^{1}$, Urszula Kamińska², Magdalena Stefanowicz-Rutkowska1

${ }^{1}$ Collegium Medicum, Medical Department, Department of Internal Medicine, Clinic of Endocrinology, Diabetology and Internal Medicine, University of Warmia and Mazury in Olsztyn

${ }^{2}$ Clinical Department of Neurology, Voivodeship Hospital in Olsztyn

\title{
Diagnosis and treatment of diabetic retinopathy - historical overview
}

\section{ABSTRACT}

Before the discovery of insulin, diabetes had been a fatal disease. Insulin extended lifespan of diabetic patients, yet it also gave rise to a number of chronic vascular complications, including diabetic retinopathy. Ophthalmic lesions were first observed in 1798 by John Rollo. Precise assessment of the eye fundus became possible following the construction of ophthalmoscope, which later made it possible to propose a classification of diabetic eye disease. The history of diabetic retinopathy encompasses not only the discovery of diagnostic methods such as fluorescein angiography, ultrasound examination or optical coherence tomography, but also the history of its treatment.

Both initially as well as at present, clinical nutrition constitutes the most important aspect of treatment. DCCT and UKPDS have shown that good metabolic balance plays a significant role in preventing and treating DR. Further studies proved that pharmacological treatment based on fibrates and angiotensin-convertingenzyme inhibitors. A turning point in the history of DR treatment appeared when laser photocoagulation was introduced in 1959. The discovery of epidermal growth factor in 1982 led to the use of anti-VEGF medications in treating maculopathy. Surgical treat-

Address for correspondence: lek. Wojciech Matuszewski

Klinika Endokrynologii, Diabetologii i Chorób Wewnętrznych Wydział Nauk Medycznych

Uniwersytet Warmińsko-Mazurski, Olsztyn

ul. Żołnierska 18, 10-561 Olsztyn

e-mail: wmatuszewski82@wp.pl

Clinical Diabetology 2017, 6, 5, 182-188

DOI: $10.5603 /$ DK.2017.0030

Received: 13.11.2017

Accepted: 30.11 .2017 ment of DR primarily consisted of vitrectomy whose procedures are continually improved. (Clin Diabetol 2017; 6, 5: 182-188)

Key words: diabetes, complication, diabetic retinopathy

\section{Introduction}

The history of diabetes reaches as far as ancient times. The first reports date back to 3500 years ago and come from the ancient Egypt. The first clinical description of diabetes was presented in the Ebers Papyrus from $1530 \mathrm{BC}$. Then a lot of attention was paid to patients' urine, which - as Characa, a doctor living in India in 800-200 BC, noticed - "attracted ants and flies". Hippocrates (466-377 BC) described diabetes as a disease with polyuria which led to emaciation. The word "diabetes" from the Greek "syphon", as "the flow of water though the body" was first used by Aretaeus of Cappadocia (30-90 AD). He was also first to present a full clinical description of a patient with diabetes [1, 2]. In turn, the term "diabetes mellitus" was first used by John Rollo in 1797 [3]. In 1889, Minkowski and von Mering proved a correlation between diabetes and islets of Langerhans [4]. However, it was the discovery of insulin in 1922 by Banting, Macleod, Best and Collip that constituted a breakthrough. For their work the scientists received a Nobel Prize in physiology $[5,6]$. Introducing insulin, and in the subsequent years also other antiglycemic medications, into the treatment of diabetes resulted in extending the lifespan of diabetic patients, yet it also started an era of chronic vascular complications, including those of the eye [7] (Fig. 1). 


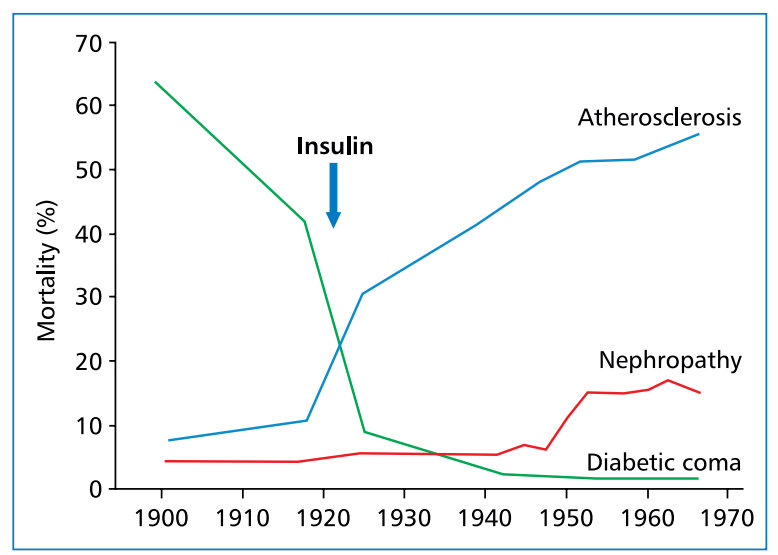

Figure 1. The mortality of patients with diabetes before and after the discovery of insulin [7]

\section{Diagnosing diabetic retinopathy}

Although diabetes has been known since 3000

BC, its ocular complications came into focus only 200 years ago, while their treatment started 100 years ago. Ophthalmic lesions co-occurring in diabetes were first described in 1798 by John Rollo in a monograph devoted to eye lesions in diabetes, which also referred to a connection between diabetes and cataract. When in 1851 Helmholtz constructed an ophthalmoscope, he made it possible to diagnose and follow lesions in the fundus of the eye in diabetic patients. For the first time such lesions were described by a Viennese ophthalmologist Eduard von Jaeger, in a paper "Beiträge zum Pathologie des Auges" published in 1855. He called lesions in the fundus "retinitis diabetic" [8, 9]. Von Jaeger was the first to notice lesions perceived as diabetic maculopathy, yet his reports were back then criticised by some authors, such as Albrecht von Graefe, who denounced any connection between diabetes and changes observed in the retina [10]. Correlations between diabetes and lesions within the macula were unequivocally determined in 1969 by Henry Noyes, and confirmed three years later by Edward Nettleship, who presented them in his paper on histopathological changes in the macula in diabetic patients. Thus he provided the foundations for the current definition of diabetic maculopathy $[11,12]$.

The knowledge on the topic of ocular lesions in diabetes was publicised in 1876 by Wilhelm Manz in a richly illustrated work entitled Retinitis proliferans [13]. A year later, on the basis of post mortem examinations, Mackenzie was first to determine the presence of micro-aneurisms in the retina as lesions typical only of diabetes; he also observed bleeding into the retina and the vitreous body in diabetic patients [8]. Nine years later Nettleship reported venous beading in the retina in diabetic patients, and undertook description of proliferative retinopathy [14]. The natural history of diabetic retinopathy, including its division into four types, was presented by Julius Hirschberg in 1890, yet the full description of DR was published only in 1944 by Ballantyne and Lowenstein. They enumerated five stages of DR, which provided the basis for the current classification [15, 16]. In turn, in 1954 Lundbaek introduced the term "diabetic angiopathy", which referred to the diabetic disease of small blood vessels [17].

All the discoveries presented above contributed to outlining the classification of retinopathy proposed by the Royal College of Ophthalmology (RCO) and based on the lesions in the fundus, starting from non-proliferative retinopathy, to pre-proliferative retinopathy, to proliferative retinopathy. This division did not, however, account for maculopathy, which can co-occur with retinopathy at each of its stages. At present, there is a number of DR classifications proposed by diabetology and ophthalmology societies such as: American Academy of Ophthalmology (AAO), International Council of Ophthalmology (ICO), the RCO. There are also classifications proposed for the purpose of scientific research, for instance Early Treatment Diabetic Retinopathy Study (ETDRS). It needs emphasising that all of them make it possible to specify lesions characteristic for retinopathy as well as maculopathy [18-21]. In 1842, Christian Doppler described a phenomenon which consists in a difference of frequencies sent by a wave source and registered by an observer who moves relative to the source [22]. This discovery led to the development of Doppler ultrasonography, and thanks to Erickson and Hendrix it found its applications also in ophthalmology. In the 1990s, 3D diagnostic methods were introduced in ocular ultrasonography $[23,24]$. In the following years, optical coherence tomography (OCT) started to be employed, which allows the doctor to assess cross-sections of the cornea, vitreous body and retina, as well as optic nerve head $[25,26]$. The discovery of fluorescence and Stokes' law made it possible - already 50 years ago - to retrieve images of the retina in fluorescein angiography. Maurice pioneered analysing layers of the cornea, yet it was thanks to Nipokov's research that a confocal microscope was introduced to the diagnostics of ocular lesions, and its first version was constructed by Minsky in 1955 [27-30]. Subsequent studies were conducted by Svishcher in 1969, while Masters and Paddock analysed the cells of corneal epithelium in a confocal laser scanning microscope [28].

Over the years diagnostics employed to assess diabetic retinopathy has become more and more precise. What is more, now it reaches more and more patients 
thanks to screening programmes and development of telemedicine. The first screening tests for DR were conducted in 1980 in Iceland [31, 32]. Another mass screening programme commenced in 1991 in Singapore. It employed non-mydriatic 45-degree Topcon Polaroid fundus cameras which were operated by technicians and optometrists. The results were then assessed by ophthalmologists [33]. Currently, programmes for early detection of diabetic retinopathy are conducted in many countries in the world and unequivocally confirm their medical as well as economic effectiveness [34].

\section{Treatment of diabetic retinopathy}

Treatment of diabetic retinopathy initially meant only treating hyperglycaemia and introducing low-fat clinical nutrition in order to limit the number of hard exudates.

In 1953 Poulsen observed slower development of DR in women with postpartum pituitary necrosis. This discovery led to attempts to treat patients with proliferative DR with resection of the pituitary gland, yet the procedure proved effective only in $30 \%$ of cases. The method was abandoned because the treatment was so radical and with a risk accompanying the operation, as well as the need to implement hormonal replacement therapy subsequently [35].

The 1990s saw introduction of medications improving mechanical resistance of capillary walls and decreasing their permeability, such as calcium dobesilate or vinpocetine, yet in the subsequent years their biological impact on DR was not confirmed [36]. Drugs which failed to produce the expected effects included also: aldose reductase inhibitors, acetylsalicylic acid, sulodexide, ticlopidine, antioxidants (vitamin C, E) and rutin derivatives [37-40].

At present it is known that the most important method to prevent the occurrence and development of diabetic retinopathy consists in achieving optimal glycaemia [41]. This is based on the results of Diabetes Control and Complications Trial (DCCT) which was started in 1986. It was shown that in DM1 patients who underwent intensive treatment the risk of developing retinopathy was reduced by $76 \%$, and its progression was slowed by $54 \%$ [42]. In DM2 patients the results of United Kingdom Prospective Diabetes Study (UKPDS) which started in 1977 also confirmed a beneficial effect of intensive diabetes type 2 treatment on limiting the risk of developing retinopathy. In the UKPDS it was shown that reducing $\mathrm{HbA}_{1 \mathrm{c}}$ by $1 \%$ led to the reduction of DR progression by $21 \%$ and to a $30 \%$ reduction of the need for laser therapy. In the same study reducing systolic pressure by $10 \mathrm{~mm} \mathrm{Hg}$ reduced the risk of microangiopathy, including retinopathy, by $13 \%$ [43].
Similar results confirming the effect of good metabolic control on the risk of developing retinopathy were shown in the Wisconsin Epidemiologic Study of Diabetic Retinopathy (WESDR) conducted in 1979, and in the later Kumamoto Study (1995) as well as ACCORD-Eye (2001) [44-46].

In the 1980, studies aimed at improving lipid parameters as one of the methods to reduce diabetic retinopathy were initiated $[47,48] .1990$ s is the time when a number of studies showing a beneficial effect of improved lipid metabolism on retinopathy were published, while in 2005 the results of Fenofibrate Interventions and Event Lowering in Diabetes (FIELD) unequivocally showed that fenofibrate treatment reduced the need for laser photocoagulation in diabetic patients by $30 \%[49,50]$.

Another group of substances which exert positive impact in diabetes are statins; the first of them mevastatin - was isolated from the mold Penicillium citrinum in 1976 by Japanese researchers Akiro Endo and Masudo Kuroda. Pravostatin and simvastatin were isolated from Aspergillus terreus in 1991 [51-54].

In ETDRS it was shown that every $10 \%$ increase in cholesterol levels increased the number of hard exudates in the retina, while their number lowered not after photocoagulation but after the statin therapy $[47,55]$.

Another turning point in hypertension and diabetic retinopathy treatment consisted in the discovery of angiotensin-converting-enzyme inhibitors. It would not have been possible if it had not been for Finnish researchers Tigersted and Bergman, who 100 years ago discovered renin, a proteolytic enzyme which increased blood pressure in rabbits [56]. In 1939, American researchers Page and Helmer described angiotonin, which was later renamed to angiotensin [57]. In turn in 1950-1956 a Cleveland-based team of Leonard Skeggsisolated angiotensin-converting enzymeand subsequently its inhibitor [58]. In 1970, Ondetti and Cushman isolated a substance from viper's venom whose activity was similar to ACE inhibitor, and five years later the same researchers synthesised captopril, which was implemented in regular treatment in 1981 $[59,60]$. In DR treatment ACE inhibitors maintain a stable position and their effectiveness was proved for instance in EURODIAB Controlles Trial of Lisinopril in insulin dependent diabetes (EUCLID). Lisinopril treatment reduced the incidence of diabetic retinopathy by $30 \%$ and by $50 \%$ progression of already diagnosed DR [61]. Also a 5-year RAAS study showed reduced progression of DR by $60 \%$ in patients treated with enalapril [62].

In the recent years some hopes have been invested in application of steroids into the vitreous body or ocu- 
lar area [63]. Although most recent reports question the effectiveness of triamcynolon treatmnet, anecortave acetate and dexametazone are still applied [64, 65].

In the recent years there has also been a considerable improvement in diabetic maculopathy treatment. It was made possible thanks to discovering the VEGF (vascular endothelial growth factor) in 1982. Its participation in DR development was confirmed in 1994, showing its increased concentration in the vitreous body in PDR patients [66, 67]. The first synthesised inhibitor of this factor was pegaptanib, administered in an injection into the vitreous body, then VEGF-A antibodies ranibizumab and bevacizumab were obtained; they showed better effectiveness than pegaptanib [68]. Their first application was age-related maculal degeneration (AMD) treatment. After subsequent studies, at the beginning of 2011, ranibizumab was registered in the therapy of diabetic macular oedema $[68,69]$. At present, anti-VEGF treatment constitutes the basis for this therapy. In diabetic maculopathy also infliximab, a monoclonal antibody acting like human TNF $\alpha$, is also used. In other studies, it was shown that hyaluronidase and microplasmin reduce the risk of intraocular bleeding. Moreover, positive results of implementing protein kinase $\mathrm{C}$ inhibitors were observed impeding the development of diabetic retinopathy [70-73].

In line with better pharmacological treatment, another milestone in DR treatment consisted in laser photocoagulation of the retina. In 1959, Gerhard Meyer-Schwickerath undertook the first attempts to implement this treatment in diabetic patients [74]. The first large scale studies were conducted in 1963 by Paul Wetzing; however, it was Beetham and Aiello who fully proved the effectiveness of photocoagulation in DR treatment $[75,76]$. Patz also proved that argon laser was effective in stabilisation and improvement in diabetic maculopathy treatment [77]. In 1979, Diabetic Retinopathy Study Research Group announced that both argon as well as xenon laser reduces the risk of blindness, and a similar view was taken in 1995 by ETDRS (Early Treatment Diabetic Retinopathy study Research Group) [78, 79].

Surgical treatment in the course of ophthalmological complications is represented mainly by vitrectomy, a procedure introduced in 1971. These operations, first performed by Robert Mecherer, are mainly indicated for patients with bleeding in the vitreous body; at present they are more and more common and safe thanks to advances in microsurgery [80].

Cataract is diagnosed more often in DM2 patients, and in almost $50 \%$ of cases diabetic retinopathy is a coexisting condition. Poor metabolic control increases progression of cataract. In DM1 cataract can occur as a result of sudden fluctuations in glucose levels, which leads to changes in lens hydration. Restoring proper metabolic balance can cause almost complete regression of cataract [81-83].

Surgical cataract treatment has been practiced since thousands of years BC and initially consisted in pushing the lens into the vitreous body. Only in 1747 Jacques Daviel incised the cornea and extracted the lens [84, 85]. In 1753 Samuel Sharp removed the lens with no harm to its capsule [86]. The subsequent years saw development of the aspirational cataract removal method. One of its pioneers, Laugier, in 1847 performed aspiration through a sclerotic puncture. More than 100 years later, Scheie performed aspiration-irrigation procedure [87]. In 1949, Sir Harold Ridley was first to implant artificial lens. Although his success was only partial and caused many protests it was a huge step forward in treating cataract. In 1967 another breakthrough took place - it was phacoemulsification pioneered by Charles Kelman, a procedure which made it possible to perform "small incision surgery" [88]. At present, foldable lens are used, and they are implanted through an incision 1.8-3.2 $\mathrm{mm}$, or even 1.0-1.5 mm long, and the procedure apart from removing the cataract corrects astigmatism and presbyopia [89-91].

At present we witness a shift in the pathogenesis of diabetic retinopathy, as it is no longer a purely microvascular complication, but also a neurovascular one [92]. This turn in our thinking about retinopathy has become possible thanks to a discovery made in 1960 by Wolter and Bloodworth, who observed degeneration of neurons in the postmortem examination of the retina in diabetic patients [93]. Modern researchers claim that neurodegeneration of the retina may precede microvascular lesions typical of diabetic retinopathy. However, neurodegeneration is not a dominant pathogenic factor in all patients. What is more, diabetic retinopathy develops in diabetic patients in various manners, and its three phenotypes have been differentiated depending on progression and risk of vision loss [94, 95]. Following the revolution in pathogenesis, there appear new possibilities in treatment of diabetic retinopathy. There are promising results of studies into somatostatins and brimonidine applied locally, which increased survival and limited apoptosis of photoreceptor cells in the retina [96]. Endothelin receptor antagonists decrease apoptosis of pericytes and reduce angiogenesis [97]. It has been confirmed that lixisenatide, a GLP-1 agonist, has a protective effect on the neurovascular unit in diabetic retinopathy [98]. Local application of DPP-IV inhibitor prevented neurodegeneration in experimental diabetes [99]. A neuroprotective effect was also confirmed for rosiglitazone and fenofibrate [100, 101]. One 
should hope that research into other new compounds will also bring positive results.

\section{Summary}

Having presented all the above facts, it is necessary to emphasise tremendous knowledge, work and courage of researchers diagnosing and treating diabetes and its complications throughout the history. Physicians owe them respect and gratitude, hoping that modern scientists will live up to the expectations and provide diabetologists with tools to stop the epidemics of diabetes and its complications.

\section{REFERENCES}

1. Henschen F. On the term diabetes in the works of Aretaeus and Galen. Med Hist. 1969; 13(2): 190-192, doi: 10.1017/ /s0025727300014277, indexed in Pubmed: 4890048.

2. Bąk M. Kamienie milowe w historii cukrzycy. ITEM Publishng. Ed. I, Warszawa 2015-16.

3. Rollo J, Ruickshank W. An account of two cases of the diabetes mellitus, with remarks as they arose during the progress of the cure. Wyd C Dilly 1797: London.

4. Mering J, Minkowski O. Diabetes mellitus nach Pankreasexstirpation. Arch Exper Path Pharm. 1890; 26(5-6): 371-387, doi: 10.1007/bf01831214.

5. Bliss M. Chwały wystarczy dla wszystkich. Historia odkrycia insuliny. PTBPC, Łódź 2003.

6. Banting FG, Best $\mathrm{CH}$, Collip B, et al. Pancreatic extracts in the treatment of diabetes mellitus: preliminary report. Can Med Assoc J. 1922; 12: 141-146.

7. Marble A. Insulin - clinical aspects: the first fifty years. Diabetes. 1972; 21(2 Suppl): 632-636, doi: 10.2337/diab.21.2.s632, indexed in Pubmed: 4626568.

8. Grenfell A. History of diabetic complications. (In): Mogensen CE, Standl E (ed.) Prevention and treatment of diabetic late complications. Volume 2. de Grutyrer W. Berlin, New York 1989: 1-4.

9. Jaeger E. Retinitis diabetica. Beitrage zur Pathologie des Auges. Wien 1855: 33.

10. Von Graefe A. Ueber die mit diabetes mellitus vorkommenden Sehst $\varphi$ rungen. Dies Arch. 1858; IV: 230-234.

11. Noyes HD. Retinitis in glycosuria. Trans Am Ophthalmol Soc. 1869; 4: 71-75.

12. Nettleship E. On oedema or cystic disease of the retina. Roy. Lond Hosp Rep. 1872; VII: 343-351.

13. Manz W. Retinitis proliferans. Albrecht von Graefe's Archiv für Ophthalmologie. 1876; 22(3): 229-275, doi: 10.1007/ /bf01948667.

14. Poulsen JE. Features of the history of diabetology. Munskgaard, Kopenhaga.1982: 119-124.

15. Hirschberg J. áber diabetische Netzhautentzòndung. Dtsch Med Wochenschr. 1890; 13: 1181.

16. Ballantyne AJ, Lowenstein A. Pathology of diabetic retinopathy. Trans Opthal Soc UK. 1944; 63: 95.

17. Lundbeak K. Diabetic angiopathy. A specific vascular disease. Lancet. 1954; 1: 377.

18. The Royal College of Ophthalmologist.Diabetic retinopahy Guidelines December 2012.

19. American Academy of Ophthalmology. Preferred Practice Pattern. October 2012.

20. International Council of Ophthalmology.ICO Guidelines for Diabetic Eye Care February 2014.

21. American Academy of Ophthalmology. Podsumowanie założeń dla zalecanych algorytmów postępowania w praktyce klinicznej, tłum. Kudasiewicz-Kardaszewska A, Zagórski Z. October 2012.
22. Greenfield DS, Heggerick PA, Hedges TR. Color Doppler imaging of normal orbital vasculature. Ophthalmology. 1995; 120(11): 1598-1605, doi: 10.1016/s0161-6420(95)30822-6, indexed in Pubmed: 9098249.

23. Cusumano A, Coleman DJ, Silverman RH, et al. Three-dimensional ultrasound imaging. Clinical applications. Ophthalmology. 1998; 105(2): 300-306, doi: 10.1016/s0161-6420(98)93211-0, indexed in Pubmed: 9479291.

24. Downey DB, Nicolle DA, Levin MF, et al. 3-D Ultrasound Imaging of the Eye. Eye. 1996; 10: 75-81.

25. Kasprzak J, Kecik D, Kęcik T, et al. Metody skaningu optycznego w badaniach dna oczu. Nowa Okulistyka. 1998; 1: 7-11.

26. Huang D, Swanson E, Lin C, et al. Optical coherence tomography. Science. 1991; 254(5035): 1178-1181, doi: 10.1126/ /science.1957169.

27. Kino GS. Intermediate optics in Nipkow disk microscopes. Handbook of biological confocal microscopy. Ed. Pawley J.B., Rev. ed. New York: Plenum Press 1990: 105-111.

28. Masters BR, Thaer AA. In vivo human corneal confocal microscopy of identical fields of subepithelial nerve plexus, basal epithelial, and wing cells at different times. Microsc Res Tech. 1994; 29(5): 350-356, doi: 10.1002/jemt.1070290505, indexed in Pubmed: 7858315.

29. Maurice DM. A scanning slit optical microscope. Invest Ophthalmol. 1974; 13(12): 1033-1037, indexed in Pubmed: 4430572.

30. Petroll WM, Cavanagh HD, Jester JV. Confocal microscopy. In: Krachmer JH, Mannis MJ, Holland EJ. ed. Cornea. Mosby Vol 1, St. Louis 1997: 335-350.

31. Kristinsson J, Stefánsson E, Jónasson $F$, et al. Screening for eye disease in type 2 diabetes mellitus. Acta Ophthalmologica. 2009; 72(3): 341-346, doi: 10.1111/j.1755-3768.1994.tb02770.x.

32. Stefánsson $E$, Bek T, Porta $M$, et al. Screening and prevention of diabetic blindness. Acta Ophthalmol Scand. 2000; 78(4): 374-385, doi: 10.1034/j.1600-0420.2000.078004374.x, indexed in Pubmed: 10990036.

33. Lau HC, Voo YO, Yeo KT, et al. Mass screening for diabetic retinopathy - a report on diabetic retinal screening in primary care clinics in Singapore. Singapore Med J. 1995; 36(5): 510-513, indexed in Pubmed: 8882536.

34. Pieczynski J, Grzybowski A. Review of Diabetic Retinopathy Screening Methods and Programmes Adopted in Different Parts of the World. European Ophthalmic Review. 2015; 09(01): 49, doi: 10.17925/eor.2015.09.01.49.

35. POULSEN JE. Recovery from retinopathy in a case of diabetes with Simmonds' disease. Diabetes. 1953; 2(1): 7-12, indexed in Pubmed: 13020938.

36. Leite EB, Mota MC, de Abreu JR, et al. Effect of calcium dobesilate on the blood-retinal barrier in early diabetic retinopathy. Int Ophthalmol. 1990; 14(2): 81-88, doi: 10.1007/bf00154206, indexed in Pubmed: 2187006.

37. Renier G, Mamputu JC, Desfaits AC, et al. Monocyte adhesion in diabetic angiopathy: effects of free-radical scavenging. J Diabetes Complications. 2003; 17(2 Suppl): 20-29, doi: 10.1016/s10568727(02)00271-4, indexed in Pubmed: 12623165.

38. Sun W, Gerhardinger C, Dagher Z, et al. Aspirin at low-intermediate concentrations protects retinal vessels in experimental diabetic retinopathy through non-platelet-mediated effects. Diabetes. 2005; 54(12): 3418-3426, doi: 10.2337/diabetes.54.12.3418, indexed in Pubmed: 16306357.

39. Szaflik J, Kamińska A. Przydatność Vessel Due F (sulodeksydu) w leczeniu pacjentów z retinopatią cukrzycową, zwyrodnieniem plamki związanym z wiekiem oraz w zakrzepicy żył siatkówki. Okulistyka. 2000; 3: 49-51.

40. Otani A, Takagi H, Oh H, et al. Vascular endothelial growth factor family and receptor expression in human choroidal neovascular membranes. Microvasc Res. 2002; 64(1): 162-169, doi: 10.1006/ /mvre.2002.2407, indexed in Pubmed: 12074642.

41. Polskie Towarzystwo Diabetologiczne. Zalecenia kliniczne dotyczące postępowania u chorych na cukrzycę 2016. Stanowisko 
Polskiego Towarzystwa Diabetologicznego. Diabetologia Kliniczna. 2016; 5(suppl. A).

42. Nathan DM, Genuth S, Lachin J, et al. Diabetes Control and Complications Trial Research Group. The effect of intensive treatment of diabetes on the development and progression of long-term complications in insulin-dependent diabetes mellitus. N Engl J Med. 1993; 329(14): 977-986, doi: 10.1056/ /NEJM199309303291401, indexed in Pubmed: 8366922

43. UKPDS Group. Intensive blood-glucose in patients with type 2 diabetes. Lancet. 1998; 352(9131): 837-853.

44. Klein R. The Wisconsin Epidemiologic Study of Diabetic Retinopathy. Archives of Ophthalmology. 1984; 102(4): 527, doi: 10.1001/ /archopht.1984.01040030405011.

45. Ohkubo $Y$, Kishikawa $H$, Araki $E$, et al. Intensive insulin therapy prevents the progression of diabetic microvascular complications in Japanese patients with non-insulin-dependent diabetes mellitus: a randomized prospective 6-year study. Diabetes Res Clin Pract. 1995; 28(2): 103-117, doi: 10.1016/0168-8227(95)01064k, indexed in Pubmed: 7587918.

46. Action to Control Cardiovascular Risk in Diabetes Follow-On (ACCORDION) Eye Study Group and the Action to Control Cardiovascular Risk in Diabetes Follow-On (ACCORDION) Study Group. Persistent Effects of Intensive Glycemic Control on Retinopathy in Type 2 Diabetes in the Action to Control Cardiovascular Risk in Diabetes (ACCORD) Follow-On Study. Diabetes Care. 2016 Jul; 39(7): 1089-1100.

47. Early Treatment Diabetic Retinopathy Study Raport, Number22:association of abstract serum lipid levels with retinal hard exudate in diabetic retinopathy. Arch Ophthalmol. 1987; 94: 1614-1620.

48. Klein B, Moss S, Klein R, et al. The Wisconsin Epidemiologic Study of Diabetic Retinopathy. Ophthalmology. 1991; 98(8): 1261-1265, doi: 10.1016/s0161-6420(91)32145-6.

49. Gordon B, Chang S, Kavanagh M, et al. The effects of lipid lowering on diabetic retinopathy. Am J Ophthalmol. 1991; 112(4): 385-391, doi: 10.1016/s0002-9394(14)76244-0, indexed in Pubmed: 1928239.

50. Keech A, Simes RJ, Barter P, et al. FIELD study investigators. Effects of long-term fenofibrate therapy on cardiovascular events in 9795 people with type 2 diabetes mellitus (the FIELD study): randomised controlled trial. Lancet. 2005; 366(9500): 1849-1861, doi: 10.1016/S0140-6736(05)67667-2, indexed in Pubmed: 16310551.

51. Endo A, Hasumi K, Negishi S. Monacolins J and L, new inhibitors of cholesterol biosynthesis produced by Monascus ruber. J Antibiot (Tokyo). 1985; 38(3): 420-422, indexed in Pubmed: 3839227.

52. Endo A, Kuroda M, Tsujita Y. ML-236A, ML-236B, and ML-236C, new inhibitors of cholesterogenesis produced by Penicillium citrinium. J Antibiot (Tokyo). 1976; 29(12): 1346-1348, doi: 10.7164/antibiotics.29.1346, indexed in Pubmed: 1010803.

53. Graaf MR, Richel DJ, van Noorden CJF, et al. Effects of statins and farnesyltransferase inhibitors on the development and progression of cancer. Cancer Treat Rev. 2004; 30(7): 609-641, doi: 10.1016/j.ctrv.2004.06.010, indexed in Pubmed: 15531395.

54. Moghadasian MH. Clinical pharmacology of 3-hydroxy-3-methylglutaryl coenzyme A reductase inhibitors. Life Sci. 1999; 65(13): 1329-1337, doi: 10.1016/s0024-3205(99)00199-x, indexed in Pubmed: 10503952.

55. Cusick M, Chew EY, Chan CC, et al. Histopathology and regression of retinal hard exudates in diabetic retinopathy after reduction of elevated serum lipid levels. Ophthalmology. 2003; 110(11): 2126-2133, doi: 10.1016/j.ophtha.2003.01.001, indexed in Pubmed: 14597519.

56. Tigerstedt R, Bergman PG. Niere und Kreislauf. Skand. Arch. Physiol. 1898; 8: 223-271.

57. Page IH, Helmer OM. A crystalline pressor substance (angiotonin) resulting from the reaction between renin and renin-activator. J Exp Med. 1940; 71(1): 29-42, doi: 10.1084/jem.71.1.29, indexed in Pubmed: 19870942.
58. SKEGGS LT, KAHN JR, SHUMWAY NP. The preparation and function of the hypertensin-converting enzyme. J Exp Med. 1956; 103(3): 295-299, doi: 10.1084/jem.103.3.295, indexed in Pubmed: 13295487.

59. Ondetti MA, Williams NJ, Sabo EF, et al. Angiotensin-converting enzyme inhibitors from the venom of Bothrops jararaca. Isolation, elucidation of structure, and synthesis. Biochemistry. 1971; 10(22): 4033-4039, indexed in Pubmed: 4334402.

60. Ondetti MA, Rubin B, Cushman DW. Design of specific inhibitors of angiotensin-converting enzyme: new class of orally active antihypertensive agents. Science. 1977; 196(4288): 441-444, doi: 10.1126/science.191908, indexed in Pubmed: 191908.

61. Chaturvedi N. Randomised placebo-controlled trial of lisinopril in normotensive patients with insulin-dependent diabetes and normoalbuminuria or microalbuminuria. The Lancet. 1997; 349(9068): 1787-1792, doi: 10.1016/s0140-6736(96)10244-0.

62. Harindhanavudhi T, Mauer M, Klein R, et al. Renin Angiotensin System Study (RASS) group. Renal and retinal effects of enalapril and losartan in type 1 diabetes. N Engl J Med. 2009; 361(1): 40-51, doi: 10.1056/NEJMoa0808400, indexed in Pubmed: 19571282.

63. Martidis A, Duker J, Greenberg P, et al. Intravitreal triamcinolone for refractory diabetic macular edema. Ophthalmology. 2002; 109(5): 920-927, doi: 10.1016/s0161-6420(02)00975-2.

64. Dugel PU, Bandello F, Loewenstein A. Dexamethasone intravitreal implant in the treatment of diabetic macular edema. Clin Ophthalmol. 2015; 9: 1321-1335, doi: 10.2147/OPTH.S79948, indexed in Pubmed: 26213460.

65. Boyer DS, Faber D, Gupta S, et al. Ozurdex CHAMPLAIN Study Group. Dexamethasone intravitreal implant for treatment of diabetic macular edema in vitrectomized patients. Retina. 2011; 31(5): 915-923, doi: 10.1097/IAE.0b013e318206d18c, indexed in Pubmed: 21487341.

66. Shweiki D, Itin A, Soffer D, et al. Vascular endothelial growth factor induced by hypoxia may mediate hypoxia-initiated angiogenesis. Nature. 1992; 359(6398): 843-845, doi: 10.1038/359843a0, indexed in Pubmed: 1279431.

67. Itakura H, Kishi S, Kotajima N, et al. Persistent secretion of vascular endothelial growth factor into the vitreous cavity in proliferative diabetic retinopathy after vitrectomy. Ophthalmology. 2004; 111(10): 1880-1884, doi: 10.1016/j.ophtha.2004.03.035, indexed in Pubmed: 15465550.

68. Massin P, Bandello F, Garweg JG. Safety and Efficacy of Ranibizumab in Diabetic Macular Edema (RESOLVE Study). Diabetes Care. 2010; 33: 2399-2405.

69. Kubicka-Trząska A. Skuteczna terapia nadal poszukiwana. Nowe perspektywy leczenia wysiękowej postaci zwyrodnienia plamki związanego z wiekiem. Przegląd Okulistyczny. 2005; 1: 10.

70. Sfikakis PP, Grigoropoulos V, Emfietzoglou I, et al. Infliximab for diabetic macular edema refractory to laser photocoagulation: a randomized, double-blind, placebo-controlled, crossover, 32week study. Diabetes Care. 2010; 33(7): 1523-1528, doi: 10.2337/ /dc09-2372, indexed in Pubmed: 20413522.

71. Kuppermann BD, Thomas EL, de Smet MD, et al. Vitrase for Vitreous Hemorrhage Study Groups. Pooled efficacy results from two multinational randomized controlled clinical trials of a single intravitreous injection of highly purified ovine hyaluronidase (Vitrase) for the management of vitreous hemorrhage. Am J Ophthalmol. 2005; 140(4): 573-584, doi: 10.1016/j.ajo.2005.04.018, indexed in Pubmed: 16125661.

72. Frank RN. Potential new medical therapies for diabetic retinopathy: protein kinase C inhibitors. Am J Ophthalmol. 2002; 133(5): 693-698, doi: 10.1016/s0002-9394(02)01321-1, indexed in Pubmed: 11992868.

73. Lang GE. Treatment of diabetic retinopathy with protein kinase $C$ subtype Beta inhibitor. Dev Ophthalmol. 2007; 39: 157-165, doi: 10.1159/000098506, indexed in Pubmed: 17245085.

74. Pesch KJ, Meyer-Schwickerath G, Meyer-Schwickerath G. Treatment of vascular disease of the retina with light coagulation. 
Trans Can Opthalmolog Soc. 1963; 26(6): 137-147, indexed in Pubmed: 14270901.

75. Wetzig PC, Worlton JT, Wetzig Pc, et al. Treatment of diabetic retinopathy by light-coagulation: a preliminary study. Br J Ophthalmol. 1963; 47: 539-541, doi: 10.1136/bjo.47.9.539, indexed in Pubmed: 14193661.

76. Wolfensberger TJ, Hamilton AM. Diabetic retinopathy - an historical review. Semin Ophthalmol. 2001; 16(1): 2-7, indexed in Pubmed: 15487691.

77. Patz A, Schatz H, Berkow JW, et al. Macular edema - an overlooked complication of diabetic retinopathy. Trans Am Acad Ophthalmol Otolaryngol. 1973; 77(1): OP34-OP42, indexed in Pubmed: 4738180.

78. Four risk factors for severe visual loss in diabetic retinopathy. The third report from the Diabetic Retinopathy Study. The Diabetic Retinopathy Study Research Group. Arch Ophthalmol. 1979; 97(4): 654-655, doi: 10.1001/archopht.1979.01020010310003, indexed in Pubmed: 426679

79. Focal photocoagulation treatment of diabetic macular edema. Relationship of treatment effect to fluorescein angiographic and other retinal characteristics at baseline: ETDRS report no. 19. Early Treatment Diabetic Retinopathy Study Research Group. Arch Ophthalmol. 1995; 113(9): 1144-1155, doi: 10.1001/ /archopht.1995.01100090070025, indexed in Pubmed: 7661748.

80. Macherer $\mathrm{R}$, Buettner $\mathrm{H}$, Norton WE, et al. Vitrectomy: a pars plana approach. Trans Am Acad Ophthalmol Otolaryngol. 1971; 75: 813-820.

81. Kański J. Okulistyka kliniczna. Elsevier Urban\&Partner, Wrocław 2009: 359-393.

82. Gelvin JB, Thonn VA. The formation and reversal of acute cataracts in diabetes mellitus. J Am Optom Assoc. 1993; 64(7): 471-474, indexed in Pubmed: 8376715.

83. Datlies MB, Kinoshita IM. Pathogenesis of cataracts. Clinical ophthalmology. (In:) Duane's clinical ophthalmology. Tasman W, Jaeger EA (ed) Lippincott Filadelfia 1992: 1-14.

84. Melanowski WH. Dzieje Okulistyki. Państwowy Zakład Wydawnictw Lekarskich, Warszawa 1972; 1-24, 134-142.

85. Musiał G. Historia operacji zaćmy. Klin Oczna. 1983; 85: 325-327, 371-373, 439-441.

86. Kałużny J. Soczewka i zaćma.(Seria: Basic and Clinical Science Course, część 11). Elsevier Urban \& Partner, Wrocław 2007: 21-76, 93-120.

87. Musiał G. Historia operacji zaćmy. Klin Oczna. 1983; 85: 325-327, 371-373, 439-441.

88. Apple DJ. Sir Harold Ridley and his fight for sight. Slack, Thorofare 2006: 128-148.

89. Alió J, Rodriguez-Prats JL, Galal A. Advances in microincision cataract surgery intraocular lenses. Curr Opin Ophthalmol. 2006; 17(1): 80-93, doi: 10.1097/01.icu.0000192520.48411.fa, indexed in Pubmed: 16436929.
90. Bellucci R. Multifocal intraocular lenses. Curr Opin Ophthalmol. 2005; 16(1): 33-37, doi: 10.1097/00055735-200502000-00006, indexed in Pubmed: 15650577.

91. Yang J, Wang $X$, Zhang $H$, et al. Clinical evaluation of surgery-induced astigmatism in cataract surgery using $2.2 \mathrm{~mm}$ or $1.8 \mathrm{~mm}$ clear corneal micro-incisions. Int J Ophthalmol. 2017; 10(1): 68-71, doi: 10.18240/ijo.2017.01.11, indexed in Pubmed: 28149779.

92. Barber AJ. A new view of diabetic retinopathy: a neurodegenerative disease of the eye. Prog Neuropsychopharmacol Biol Psychiatry. 2003; 27(2): 283-290, doi: 10.1016/S0278-5846(03)00023-X, indexed in Pubmed: 12657367.

93. CUNHA-VAZ J. Neurodegeneration as an early event in the pathogenesis of Diabetic Retinopathy: A multicentric, prospective, phase II-III, randomised controlled trial to assess the efficacy of neuroprotective drugs administered topically to prevent or arrest Diabetic Re. Acta Ophthalmologica. 2012; 90: 0-0, doi: 10.1111/j.1755-3768.2012.2825.x.

94. Santos AR, Ribeiro L, Bandello F, et al. European Consortium for the Early Treatment of Diabetic Retinopathy (EUROCONDOR). Functional and Structural Findings of Neurodegeneration in Early Stages of Diabetic Retinopathy: Cross-sectional Analyses of Baseline Data of the EUROCONDOR Project. Diabetes. 2017 66(9): 2503-2510, doi: 10.2337/db16-1453, indexed in Pubmed: 28663190.

95. Cunha-Vaz J, Ribeiro L, Lobo C. Phenotypes and biomarkers of diabetic retinopathy. Prog Retin Eye Res. 2014; 41: 90-111, doi: 10.1016/j.preteyeres.2014.03.003, indexed in Pubmed: 24680929.

96. Arroba Al, Mazzeo A, Cazzoni D, et al. Somatostatin protects photoreceptor cells against high glucose-induced apoptosis. Mol Vis. 2016; 22: 1522-1531, indexed in Pubmed: 28050125.

97. Chou JC, Rollins SD, Ye M, et al. Endothelin receptor-A antagonist attenuates retinal vascular and neuroretinal pathology in diabetic mice. Invest Ophthalmol Vis Sci. 2014; 55(4): 2516-2525, doi: 10.1167/iovs.13-13676, indexed in Pubmed: 24644048.

98. Acunman K, Kolibabka M, Dietrich N, et al. Lixisenatide protects the neurovasular unit in diabetic retinopathy. Lisbon EASD 2017. Session: Novel treatments of retinopathy; Poster. 1045.

99. Hernández C, Bogdanov P, Solà-Adell C, et al. Topical administration of DPP-IV inhibitors prevents retinal neurodegeneration in experimental diabetes. Diabetologia. 2017; 60(11): 2285-2298, doi: 10.1007/s00125-017-4388-y, indexed in Pubmed: 28779212.

100. Li $P, X u X$, Zheng $Z$, et al. Protective effects of rosiglitazone on retinal neuronal damage in diabetic rats. Curr Eye Res. 2011; 36(7): 673-679, doi: 10.3109/02713683.2011.572220, indexed in Pubmed: 21599458.

101. Bogdanov $P$, Hernández $C$, Corraliza $L$, et al. Effect of fenofibrate on retinal neurodegeneration in an experimental model of type 2 diabetes. Acta Diabetol. 2015; 52(1): 113-122, doi: 10.1007/ /s00592-014-0610-2, indexed in Pubmed: 25029994. 